\title{
Neo-liberal or not? Creeping enclosures and openings in the making of fisheries governance
}

\author{
Courtenay Parlee ${ }^{1,2} \cdot$ Paul Foley $^{2}$ (I)
}

Received: 3 May 2021 / Accepted: 5 December 2021 / Published online: 3 March 2022

(c) The Author(s) 2022

\begin{abstract}
Neo-liberalism can mean different things from different perspectives. Social scientists tend to use the concept to identify and critique trends of privatization, marketization, commodification and enclosures, and their associated slew of exclusionary, dispossessive, and regressive effects. Counterintuitively, governmentality analyses identify how practices of collaboration, inclusion, participation, and empowerment—practices sometimes cited as means to resist and generate alternatives to neo-liberalism - are not only consistent with neo-liberal governing but also central to its functioning. This paper engages a biopolitics and governmentality analytical perspective to examine different kinds of fisheries policies in Newfoundland and Labrador (NL), Canada, where the historic cod collapse created a laboratory for examining social-ecological effects of capitalist overexploitation, resource mismanagement, and knowledge system blind spots. The case is useful because it includes, on the one hand, practices traditionally seen as reinforcing neo-liberal governance, such as property making, resource management access rationalization, and global eco-labels, and, on the other hand, practices where linkages to neoliberalism require more critical assessment, such as fisher-influenced professionalization policies, license collaboration/ consolidation initiatives, and producer-oriented eco-labels. Drawing on a governmentality perspective, this paper examines how governance change in NL fisheries is driven not by a single regulatory logic but, rather, by diverse "technologies of government" and "technologies of agency." Diverse technologies of agency, with varying degrees of links to neo-liberalism, facilitate "creeping" enclosures and openings for fish harvesters in NL fisheries. The paper finds that multi-faceted social protection and coastal community-oriented rationalities of fisher groups are key explanatory variables in shaping practices for and against neo-liberal governance, suggesting that the relationship of diverse neo-liberal, moral economy and hybrid governmentalities to lived experiences requires more empirical and theoretical attention.
\end{abstract}

Keywords Neo-liberalism $\cdot$ Fisheries $\cdot$ Enclosure $\cdot$ Governmentality $\cdot$ Biopolitics $\cdot$ Governance

\section{Introduction}

This paper seeks to contribute to a reinvigorated, theoretically engaged social science research agenda for fisheries (Bavinck et al. 2018) by engaging with conceptual and

Paul Foley

pfoley@grenfell.mun.ca

Courtenay Parlee

Courtenay.Parlee@dfo-mpo.gc.ca

1 Fisheries and Oceans Canada, Dartmouth, Nova Scotia, Canada

2 Environmental Policy Institute, School of Science and the Environment, Memorial University of Newfoundland (Grenfell Campus), Corner Brook, Newfoundland and Labrador, Canada social struggles over the contested concept of neo-liberalism (Castree 2008; Bakker 2010). Over the last thirty years, neo-liberalism has been the subject of considerable scholarly interest and debate as a force for shaping the governance of biophysical problems and resources throughout the world. Anthropologists, human geographers, political ecologists, political economists, and interdisciplinary scholars have been at the forefront of a global dialogue on the concept and its societal-ecological implications. Citing geographer Noel Castree's categorizations of neo-liberal policies, Pinkerton and Davis (2015) define neo-liberalism as a set of trends including (1) establishment of private property rights, (2) market transferability of things previously not transferable, (3) public policy de-regulation, (4) market-accommodating forms of regulation, (5) state use of market-proxies and valorization in service provision, 
(6) the general encouragement of voluntary civil society action in societal problem-solving, and (7) the promotion of self-sufficiency, particularly by individuals and communities. The concept of neo-liberalism has featured prominently in critical social science literature on fisheries governance, particularly with respect to processes of privatization (private property making) and commodification (marketability and tradability) of resource access (e.g., Mansfield 2004; Pinkerton and Davis 2015; Bresnihan 2016). The most widely analyzed and critiqued neo-liberal governance tool in fisheries is individual transferable quotas (ITQs). ITQs were introduced and justified widely in the closing decades of the twentieth century as a fisheries management panacea to avoid outcomes predicted by the flawed "tragedy of the commons" metaphor by transforming limited allocations or shares of fish into commodified property rights (see Pinkerton 2013; Edwards and Pinkerton 2019, 2020; Olson 2011; Carothers 2015; Carothers and Chambers 2012; Young et al. 2018). Other prominent governance mechanisms critiqued as neo-liberal include rationalization initiatives promoting efficiency, conservation-oriented eco-labeling and certification programs, and even participatory and decentralized forms of governance such as community-based management and co-management (Mansfield 2004: 321; Said et al. 2016; Konefal 2013; Foley and Hebért 2013; Bresnihan 2016). In general, these and other analyses have emphasized how neo-liberalism threatens small-scale fisheries, labor interests, and communities and drives complex forms of resistance and governance hybridization (Pinkerton and Davis 2015; Bresnihan 2016; Foley and Havice 2016; Foley 2017, 2019a; Pinkerton 2017).

Other literature has identified more ambiguous relations associated with neo-liberalism. Any sweeping characterization of complex governance processes in terms of purely negative and exclusionary dimensions runs the risk of missing diverse and sometimes hybrid institutional forms, agency, decision-making, and identity within, against and outside neo-liberalism (Gibson-Graham 2006, 2008). While privatization and ITQs receive significant scholarly attention among fisheries social scientists, the relationship between diverse institutional forms and practices to neo-liberalism is less clear. Such diverse and hybrid institutional forms, agency, and decision-making require more careful empirical and analytical attention (St. Martin 2005a, b; 2007). Like the broader literature on neo-liberal natures (Bakker 2010), there is a tendency in critical fisheries scholarship to focus singularly on the usual suspects of private property and ITQs and miss subtler questions, institutions, and processes of resource and market governance (Bresnihan 2016). Analysts are thus increasingly forced to contend with explaining the productive as well as the destructive; the inclusionary as well as exclusionary; and the unambiguous as well as the ambiguous forces and practices of neo-liberalism.

This paper joins fisheries scholars who draw on Foucault to explain how new and changing modes of capitalist appropriation and governance that might appear purely exclusionary rely on productive regimes of knowledge-making and rationalities that know and organize ecological and life processes (Bresnihan 2016; Foley et al. 2018; Bresnihan 2019a, b). For Foucault, neo-liberalism is not only advanced through powerful state agencies and law or corporate agents that restrict and destroy life but also through biopower. Biopower reflects a new art of government or governmentality of managing populations without direct, detectable instruments but rather through obscure forms of pragmatism and tactics. It is a power of production that aims at fostering life through diffuse state and non-state forms of administration and ordering in contemporary societies (Bresnihan 2016). From this perspective, some practices typically understood as informed by purely and narrowly neo-liberal rationalities, like market-oriented auditing and certification, have the potential to be shaped by social justice and moral economy rationalities (Foley et al. 2018). This points to the importance of understanding multiple, overlapping, and conflicting forms of governmentalities, and in the case of environmental governance, environmentalities (Fletcher 2017). Alternatively designed practices and technologies of government can thus contest regressive neo-liberal environmentalities, transforming what might appear superficially as purely neoliberal tools into tactics for supporting social justice and moral economy objectives of sustainable development.

This paper employs such a "multiple environmentalities" perspective (Fletcher 2010, 2017; Foley et al. 2018) to explore the potential for social justice-oriented environmentalities in the governance of natural resources within and outside formal practices of neo-liberalism. This approach permits the critical analysis of not simply identifying narrowly neo-liberal environmentalities, but also labor-driven/oriented and community-driven/oriented environmentalities. A multiple environmentalities perspective allows analyses to enhance practical knowledge for the development and application of ethically and morally progressive technologies of governance through knowledge, institutional design, and subject formation. Empirically, rather than focus on one neo-liberal instrument, such as ITQs or eco-certifications, this paper will examine interventions of various actors in the development and implementation of several fisheries programs and practices within Newfoundland and Labrador, Canada. The objective is to reveal the multiple ways neo-liberal governance practices are implemented, resisted, and hybridized in particular environmental, social, and institutional contexts. The analysis includes policies typically analyzed in fisheries scholarship as neo-liberal-friendly, such as limited 
entry licensing, individual quotas, and eco-certification, as well as policies that have a less clear relationship to neo-liberalism, such as owner-operator protection policies designed to restrict corporate ownership, professionalization legislation designed to protect those who depend the greatest on the fishery for livelihoods, and license combining policies designed to increase the financial viability and safety of small-scale fishing enterprises. Rather than focus on how fisheries are becoming neoliberal through a single, powerful governance instrument, this paper examines multiple processes that together suggest that neo-liberalism is simultaneously being enacted, challenged, and changed over time. To explain the effects of multiple governance processes, we also draw on but expand a concept used by Murray and colleagues (Murray et al. 2010) to propose that some of the policies and programs might be better understood as contributing to a contradictory process of "creeping" enclosure and "creeping" openings of access to fishing, where fish harvesters exert agency in making and re-making governance through and against neo-liberalism.

The remainder of the paper is structured as follows. In the next section, the conceptual approach will be introduced, focusing on key concepts in the governmentality approach, including biopolitics, rationalities of government, technologies of government, including technologies of agency, and the multiple environmentalities perspective. Next, we examine fisheries governance practices in Newfoundland and Labrador shaped by neo-liberal rationalities and by social-justice-oriented rationalities, as well as by rationalities that do not easily rest in either category. The empirical analysis is divided into an assessment of six different categories of technologies of agency within the NL context. The empirical data for these sections was gathered through a variety of published and gray literature and field research based on in-depth key informant interviews with 24 participants conducted between May and November of 2019. The extensive document review and targeted fieldwork with key informants enabled the reconstruction of the emergence and evolution of key policies and practices, revealing diverse micro-rationalities and politics resulting in creeping enclosure and creeping openings for fish harvesters. The research revealed multiple perspectives and experiences of different actors, such as staff of the Fish, Food and Allied Workers (FFAW)-Unifor union; professional fish harvesters; staff of the Professional Fish Harvesters Certification Board, staff from a social enterprise organization, buyers, processors, and provincial government employees in Newfoundland; and federal government employees. The conclusion reflects on the findings and calls for further research and practical engagement in understanding and advancing alternative, social justice and moral economy-oriented regimes of knowledge-making and rationalities that know and organize life processes.

\section{Conceptual approach: biopolitics and governmentality}

The concept of biopolitics is associated with the governmentality approach initially theorized by Michel Foucault. It refers to the emergence and spread of a new liberal art of government (governmentality) in the last two centuries. Governmentality is a type of governance that seeks to shape and regulate individuals in particular ways through a plurality of tactics so that they do not need to be regulated by others but can govern and care for themselves (Miller and Rose 2008:204). This art of governing is concerned with forms of power that operate within and beyond the state, across distances and domains (Miller and Rose 2008: 10). Along with the historically specific meaning of the concept, secondary commentators within the field have developed and used a more generic definition (McKee 2009: 466; see for example Miller and Rose 2008; Rose 1999; Dean 2010; Dean 2017; Larner 2000). The governmentality literature is underpinned by a perspective on power that is productive of meaning, intervention, entities, and processes (Miller and Rose 2008; McKee 2009). Furthermore, power is understood as not being captured solely by the state; power is distributed widely (Foucault 1991). Asking what governmentality might offer critical policy analysis, McKee (2009) states that the work of these scholars has broadened our understanding of how we think about the nature and practice of government. Miller and Rose (2008:15-16) use Foucault's concept of governmentality to tease apart two distinct aspects of the art of governing.

Although distinct, the two forms or arts of governing do not represent different domains found in reality but rather they are intrinsically linked as representing and knowing a phenomenon, and then acting on it so as to transform it (ibid:15). The first aspect is referred to as "rationalities" or "programs" which are ways of rendering aspects of life thinkable in a way that they become amenable to calculation and programming. Rationalities are the ends and means through which governmental objectives are articulated, and they materialize through thought, knowledge, vocabulary, discourse, language, decisions, strategies, and judgements (ibid; Dean 2010). To become useful, rationalities are converted from a concept into "technologies of government" which are the second key characteristic of governmentality (ibid: 16). Technologies of government are the diverse and heterogenous means, mechanisms, and instruments through which governing is accomplished through the active participation of governance subjects (Dean 2010: 269). These practical features of government include devices, tools, techniques, personnel, and apparatuses and (i) typically assemble diverse elements, 
(ii) take part in techno-economic systems, (iii) constitute logistical and infrastructural powers, and (iv) subsume the moral and political shaping of conduct (Dean 2010:270; also see Rose 1999; Miller and Rose 2008). Technologies of government have been further distilled into various categories (see Rose 1999), including technologies of agency, technologies of consumption or market, and technologies of performance.

This paper uses such sub-technologies of government as analytical tools to organize the empirical content in relation to inshore fish harvesters in NL, framing the analysis particularly with the concept of technologies of agency. Technologies of agency seek to establish or enhance the capacity of individuals and groups to act independently and make their own free choices, often in contexts of risk (Dean 2010:196), though the integration of other technologies such as market and performance are important. Centering the analysis on technologies of agency focuses our attention of techniques of empowerment, consultation, and negotiation, in addition to instruments of voice and representation. Such technologies can be co-constituted by other technologies. Technologies of market, for example, can include advertising, market research, and niche-marketing. These mechanisms allow individuals and groups to create a public image that is perceived as pleasurable, respectable, unique, and socially normal based on what they buy and sell (Rose 1999:86). Technologies of performance include audits, the setting of performance indicators and the establishment of quasi-markets in expertise and service provision in order to shape conduct. These types of technologies present themselves as strategies to restore trust by providing a direct means to transform individuals into calculating individuals within calculable spaces (Dean 2010: 197).

The governmentality approach is also useful to understand contemporary governance processes in fisheries because it provides a lens through which the micro-rules, practices, and agency of the state and other actors under conditions of neo-liberalism can be examined (Parlee and Wiber 2011; 2014; Bresnihan 2016; Johnsen 2017; Foley et al. 2018). As Bresnihan notes with reference to fisheries scientists, managers, and policy makers' common commitment to make policies work "on the ground" and to achieve measurable common goals (2016: 14), "There was never any overarching, authoritative plan for the fisheries, and it is this openness that makes neoliberal nature-making so difficult to contest. In this sense, neoliberalization is better understood as an activity (rather than a set of institutions) that both responds to and shapes the different social and ecological contexts it operates in." It is more useful, from this perspective, to examine the rationalities and technologies of government in particular contexts. This means moving beyond the tendency to identify only the agency of the state and powerful market actors and institutions, even in forms of decentralized management. Our starting point is that rationalities and technologies of government preferred and employed by powerful agents are being molded, shaped, and resisted by governance subjects that have histories of active actions against particular neo-liberal practices. By analyzing such dynamics in particular places, this paper joins the critical literature on neo-liberalism that suggests policies cannot be solely understood as a derivative of a singular neoliberal movement or regulatory moment but must be considered within the context of past policy landscapes, power and political dynamics, contestation, and biophysical and geographical characteristics and processes that result in enclosures, openings, and change for fish harvesters and small-scale producers over time (Mansfield 2004; also see Bakker 2010; St. Martin 2007; Foley et al 2015; Bresnihan 2016; Foley and Mather 2019). But what does this mean for the way that neo-liberalism is acted upon or not, for how we conceive of neo-liberalism, and for what we judge to be of consequence in that conception?

A key question is whether there is potential for distinctive social justice-oriented governmentalities in the governance of natural resources generally (Fletcher 2010) and fisheries specifically (Foley et al. 2018). Through an assessment of ways in which the concept of governmentality has been applied to analyze processes of environmental governance, Fletcher (2017) identifies how the concept of environmentality has been used by different scholars to refer to different kinds of environmental politics. Fletcher identifies distinct uses, such as a (i) sovereign environmentality in analyses of "command and control" state instruments, (ii) disciplinary modes of environmentality in analyses of participatory efforts to create people who care about and self-regulate the environment, and (iii) neoliberal environmentality, whereby market principles and incentives are privileged (Fletcher 2017). Understanding these distinctions are important because research has revealed that the practice and implementation of environmental governance are normally carried out not under a unified strategy of governance but, rather, through the operationalization of multiple strategies concurrently. Yet in most situations, the complex maneuverings of governance practice through different technologies of government, as we shall see below, remain "largely invisible-either to those directly involved within it or to the researchers reporting upon it-as we have lacked the conceptual language needed to describe it" (Fletcher 2017: 313). A multiple environmentalities lens, therefore, can help reveal differences in strategies through which different technologies of government are enacted and interact.

From this perspective, we can hypothesize that the effects of different governance strategies and different technologies of government in a particular place where neo-liberal governance instruments are enacted will be complex, often subtle and contradictory. Murray and colleagues (Murray et al. 
2010) develop the useful "creeping" enclosure concept to describe the cumulative effects that multiple rationalities, technologies, and events can have on fish harvesters' ability to gain access to and benefit from fish in the sea. Creeping enclosure entails increasing barriers to access common pool resources not because of a single regulatory moment or logic, such as a neo-liberal policy, but instead because of the cumulative effects of multiple regulatory changes. The cumulative effects can include both direct and indirect impacts; they can result from multiple forces pushing in different directions by different agents, and do not always feature privatization, marketization, or commodification. In the case study below, the evolution of multiple technologies of agency together result in similar processes of creeping enclosures but also creeping openings for fish harvesters to access and benefit from fisheries. It is therefore useful to ally concepts of creeping enclosure and opening with a multiple environmentalities perspective so as to better identify and conceptualize the multiplicity of regulatory conditions, changes, and effects, some of which might emanate from neo-liberal rationalities and technologies of agency and some of which might emanate from alternative rationalities. There is also, we suggest, practical significance to the specific recognition of agency in, and everyday social relations and practices of, creeping enclosures and creeping openings that are embedded in global and national structures of economic and political power. Shining light on different agency and interests demonstrates how social relations and practices are productive of hybrid and new institutions. A focus on fish harvester experience and agency, for example, can reveal that people "might act at a distance from dominant economic and governmental rationalities, not through explicit resistance but through practical forms of world-making that rely on and constituted different ways of knowing and doing" (Bresnihan 2016: 21). While outside observations might tend to focus on social relations and practices connected to the most obvious global and national power structures (i.e. ITQs, eco-labels), fine-grained analysis of changing fisheries governance in places such as NL suggests that other institutions and practices have as much meaning and significance to fish harvester's everyday lives, working conditions, and social-ecological relations.

\section{Technologies of agency in Newfoundland and Labrador fisheries governance}

As explained above, technologies of government include devices, tools, techniques, personnel, and apparatuses that enable state and non-state authorities to understand and act upon the conduct of individuals and groups, often in locations distant from centers of authority and power. According to Dean (2010), technologies of agency become an important factor when individuals, groups, or communities become the target of a rationality or program because they, or something they do, have been identified as a risk which requires intervention and management. Under these circumstances, targeted populations become encouraged to actively participate in monitoring and managing their own risk. However, a risk can be analyzed in terms of various and sometimes competing norms from different bodies of knowledge and expertise (Miller and Rose 2008:15). As such, the agency of individuals and groups can also be used to resist or counteract attempts to be targeted, rendered problematic, and governed. Below, we reveal these countervailing tendencies by including the agency and interests of fish harvesters in different technologies of agency. These technologies and the forces of interaction they generate result in creeping enclosure and creeping openings for fish harvesters.

\section{Enclosure and limited-entry licenses}

Contemporary fisheries policies and legislation in what is now the Canadian province Newfoundland and Labrador emerged out of a context deeply shaped by settler colonialism, commodity frontierism, and state enclosure of socialecological life reproduction through periods of significant risk and transformation, including following Canadian state enclosure in the 1970s under the auspices of the United Nations Convention on the Law of the Sea and following the Atlantic cod collapse in subsequent decades (Foley 2019b). For the Government of Canada, the contemporary conditions for governing access for fisheries and coastal communities were fundamentally changed in the 1970s with the introduction of UN-sanctioned Exclusive Economic Zone (EEZ), rationalized as providing states with the authority necessary for the conservation and optimal utilization of the vast resources of the sea. This rationalization of the global oceans enclosed, in an unprecedented way, the richest life producing parts of the oceans as state property (Campling and Havice, 2014) just as neo-liberal policies began to sweep across the Global North. Yet the process was not a homogenous process of neo-liberalization in NL, which relinquished control over managing limited adjacent ocean areas when it became a province of Canada in 1949. Through efforts to meet efficiency and equity objectives, federal public policy in Canada throughout the 1970s and 1980s created technologies of agency that enabled actors to both constitute and resist neo-liberal rationalities (Matthews 1988; Foley et al. 2015; Barnett et al. 2017: 62). During this period, state property was transformed in de facto private property through individual quotas, individual transferable quotas, and rationalization programs aimed at reducing the number of fishers, while other powerful policies and practices were 
developed to mitigate against the commodification of access rights and corporate consolidation.

The most direct technology of agency that the Government of Canada utilized for formalizing access is the fishing license. For DFO, a fishing license is:

an instrument used by the Minister, under the authority of the Fisheries Act, [that] grants authorization to a person, including an Aboriginal organization, to harvest certain species of fish or marine plants subject to the conditions attached to the license. This is a temporary grant as licenses are issued for a fixed period, usually annually. (DFO 2017a, b)

Licenses for different fish species were established in contexts of broader rationalities and technologies of government. Developed partly in preparation for the extension of fisheries jurisdiction, Canada's Commercial Fisheries Policy of 1976, for example, aimed at rationalizing the fishery (Smith et al. 2012) and improving efficiency in the use and management of fishery resources in the hopes of addressing issues arising from the "common pool" nature of wild fisheries (DFO 2001; Foley et al. 2015). While rudimentary, Canada's early experiments in commercial fisheries policy contained further technologies for controlling entry into, and participation in, the commercial fishery in order to address rationalities of conservation by constraining expansion (in capacity and participants) of the fishery. Licenses constituted one of the major technologies of agency to enroll fish harvesters in such enclosure processes after the establishment of the EEZ. In addition to rationalities to constrain the numbers of fishing participants, harvesting and processing interests competed for power to control access to fish resources, foreshadowing future and ongoing conflicts (DFO 2001). The competition between these two sectors was one of the key drivers in the development of arguably moral economy rationalities and technologies designed to separate activities of harvesting and processing as instituted in the Fleet Separation Policy initiated in 1979 and the OwnerOperator Policy in 1989/1996.

\section{Fleet Separation and Owner-Operator Policies}

As a technology of agency, limited entry licenses effectively enrolled wide swaths of geographically dispersed fishers into privatized fishing governance regimes, but with access not necessarily commodified. Indeed, the 1979 Fleet Separation Policy was rationalized as a means to protect access rights of licensed inshore fish harvesters who operate vessels less than 65 feet in length by discontinuing the issuing of fishing licenses for that category of the industry to corporate and processing sectors. Through the 1980s and 1990s, an Owner-Operator Policy was also developed and formalized. The DFO's Owner-Operator Policy for Eastern Canada has the objective of protecting access to fish resources for the inshore sector and limiting corporate and absentee ownership of fishing licenses by requiring that license holders personally fish their licenses. With some exceptions, the policy specified that licenses and vessels in the inshore fleet, defined by vessels less than 65 -feet in length, must be owned by a harvester actively fishing on the vessel. These restrictions were not placed on license holders in the vessel category of over 65 feet in length because they were already owned primarily by fish processing companies (Davis 2015:324). By 1996, both the Fleet Separation Policy and the Owner-Operator Policy were uniform across Eastern Canada fishery management regions (DFO 2017a, b; Barnett et al. 2017).

Within this context, the inshore sector was further reformed through the introduction of "core" licensing, a technology of agency which was made available to a select number of multi-species enterprises. Under this concept, entry into the core group is only possible by replacing an existing enterprise (DFO 1996). This policy enclosed access further for the inshore sector, but in a way designed to support and protect a particular kind of inshore fishery characterized by independent owner-operators. In 2007, under its Fisheries Renewal initiative, DFO introduced further measures to govern this sector through a policy to Preserve the Independence of the Inshore Fleet in Canada's Atlantic Fisheries (PIIFCAF) (DFO 2017a, b), with the aim:

to reaffirm the importance of maintaining an independent and economically viable inshore fleet in which the benefit of the license holders stay with the license holders, and provide social and economic benefits to Atlantic Canada's coastal communities. (DFO 2017a, b)

Here, we observe the evolution of an approach to limited entry licensing (privatization) shaped heavily by socialand community-oriented rationalities. The PIIFCAF policy commits to ensuring and protecting distribution of benefits to (i) the sector/fleet of smaller vessels (against the larger sectors and consolidation interests) and (ii) coastal communities. According to some participants interviewed, the owner-operator and fleet separation policies are necessary protections of the inshore sector because they keep licenses in local communities and prevent their consolidation. From this perspective, these policies are antithetical to neo-liberal policy, with policy informed heavily by ethical rationalities of distributing benefits to independent smaller-scale producers and anchoring fisheries wealth in coastal communities (Neis et al. 2014:13; Foley et al. 2015).

However, these policies also reveal further nuances of the changing nature of technologies of agency in the making of, and resistance to, neo-liberal governance. A growing trend developed in recent decades where some individuals 
and corporate entities increasingly circumvented social protection policies through legal contracts called trust or controlling agreements between apparently independent owner-operators and a private creditor, usually a processing company interested in securing supply of fish (Barnett 2014; Davis 2015; Barnett et al. 2017; Elson v. Canada (Attorney General), 2017 FC 459 (CanLII)). One interview participant explained the practice: "I don't know, they are saying it is owner-operator, but it's not because a lot of these quota [licenses] are owned by companies. Instead of controlling agreements, now they rephrase it to financial agreements to work the system." While this practice allows some fish harvesters who might not have the ability to qualify for traditional financing (e.g., through a bank) to access increasingly costly fishing licenses and vessels, the license is effectively controlled by a private entity, not the harvester (Barnett 2014: 57). After years of lobbying by organizations representing independent owner-operators and litigation stemming from cases in the province of Newfoundland and Labrador, the owner-operator and fleet separation policies were strengthened through federal Bill C-68, An Act to amend the Fisheries Act and other Acts in consequence in June 2019. The Act includes new language affirming the Minister of DFO may consider "the preservation or promotion of the independence of license holders in commercial inshore fisheries," and may consider social, cultural, and economic factors in making decisions about the management of fisheries. As such, the Act reasserts the government's commitment to a rationality of strengthening the inshore sector and protecting benefits that are critical to supporting economic development and well-being in coastal communities. This aligns with other public good rationalities, such as the Government of Canada's mandate to protect the interests of Canadians in managing fisheries as a common pool resource (Fisheries Act, R.S.C. 1985, c. F-14), and the expectation that fisheries are to be managed according to a broad suite of social and economic objectives, including distribution of access and benefits to coastal regions and communities (Stephenson et al. 2018, 2019; also see Edwards and Pinkerton 2019). Given that these legislative modifications are relatively recent, "in terms of enforcing it, the jury is still out," as one participant stated, revealing the need for ongoing analysis of the lived experiences and struggles over creeping enclosures and openings in NL fisheries.

\section{Individual quotas (IQs)}

While owner-operator and fleet separation policies were designed to embed fisheries benefits in independent smallscale enterprises and in coastal communities, the history of access policies and relations following state enclosure within EEZs was marked by immediate and growing pressures to develop technologies of agency and performance through market-oriented access policies. In the early 1980s, for example, the concept of individual transferable quotas (ITQs) (exclusive rights to a quota(s) of a total allowable catch (TAC) and the ability to transfer quotas to qualified participants) gained attention in Canadian fisheries management (McCay 1999), partly influenced by recommendations in the 1982 report of the Kirby Taskforce on Atlantic Fisheries (Kirby 1982). Government and industry efforts were focused on rationalizing - that is reducing productive capacity, particularly by reducing numbers of individuals and laborers employed in the sector-the fishery towards achieving economic and social viability and improving the bankruptcy situation of many of the larger fishing companies at this time. Rationalization goals were to be realized through new technologies of agency with technologies of market, such as the merging of the five large processing companies in the province into two companies to improve the economic efficiency of the processing sector. Rationalization of the offshore sector was implemented in the 1980s through the creation of an Enterprise Allocation system for regulating access to licenses and harvesting.

Further governmental attempts to restrict access and capacity in the Atlantic fishery, particularly for groundfish stocks, led to the introduction of several other technologies of agency, including restrictions on vessel replacement and the formulation of the 1982 Sector Management Policy for Canada's Atlantic Inshore Groundfish Fishery. The Sector Management Policy for Groundfish was put in place to manage and control access to groundfish stocks between the fishing sectors, to avoid occurrences of overfishing or fishing below capacity, and in effect, to restructure the Atlantic fishery. The policy eradicated the practice whereby license holders, mainly in the inshore fleets, could fish almost everywhere on the Atlantic Coast where quotas were available, and instituted a more restricted but structured system which required license holders to fish in a defined fishing area or zone (DFO 2001). Policies, laws, and interventions were also introduced to control the groundfish fishery through access restrictions and TAC reductions (Lear and Parsons 1993). Findings by the 1987 Alverson Task Force and the 1989 Scotia-Fundy Groundfish Task Force and the 1990 Harris Panel reiterated the problem of overcapacity in Atlantic fisheries and the unhealthy decline in the stock abundance and called for interventions that would restructure the fishery and rebuild declining stocks, particularly northern cod (Alverson 1987; Hache 1989; Harris 1990).

The rationalities of overcapacity and sector rationalization played a key role in the emergence of technologies of agency such as individual quotas (IQs) in the post-cod collapse period (Davis 2015: 325). For example, the 1995 Montreal Round Table, a conference of industry-government collaboration, advocated a reduction in capacity in both harvesting and processing sectors, and recommended that IQs, 
ITQs, and Enterprise Allocations be considered if a clear majority of license holders supported the access measures (DFO 2001: 13). A report entitled Charting a New Course: Towards the Fishery of the Future also presented the concept of IQs and promoted the idea of introducing ITQs "where such management systems do not already exist" (DFO 1993: 58). After the initial cod moratorium of the early 1990s, IQs were introduced to almost all fisheries prosecuted by the inshore sector; lobster was the only species exempt from the IQ policy (Davis 2015:326).

While IQs are consistent with neo-liberal policies of privatization, the emergence of IQs as a technology of agency was also subject to modification and hybridization. For example, there was significant pressure from large fish processing and distribution companies to make them transferable, arguing it would provide fishing enterprises with the flexibility to land their catch at times that are most profitable, it would reduce the number of people dependent on the fishery and bring about greater vertical integration just as it had in other countries such as Iceland, Australia, and New Zealand. However, in NL, the union representing inshore fish harvesters and fish processing plant workers was staunchly opposed to adding a transferability component to IQs. Given the broad representation of the FFAW-Unifor in NL, they had considerable political impact in the province and successfully stifled efforts to turn IQs into ITQs (Davis 2015: 325), thus helping to maintain some critical restrictions against policy conditions that would more easily facilitate commodification and consolidation in fisheries access. In this sense, the union exerted agency over the policy design of IQs, using this technology of agency to establish their capacity to act independently and make choices in the context of a potential risk.

These tensions between enclosure and opening for inshore fish harvesters in NL continued to shape policy change through the late 1990s, when the failure of cod's recovery put enormous pressure on Canada's federal fisheries management regime. For instance, DFO's Commercial Fisheries Licensing Policy for Eastern Canada, introduced in 1996, is predominantly aimed at "reducing capacity, improving the economic viability and preventing future growth in capacity in the commercial fisheries" but also incorporates various elements and criteria associated with the protection and prioritization of inshore, small-scale, communitybased fisheries and indigenous fisheries (DFO 1996). These include the "core group" criterion, and residence or home port criterion for determining access, the adjacency principle for privileging resource access to the people who live near the resource, the owner-operator and fleet separation policies, and the recognition of Indigenous fishing rights and treaty provisions. This policy has shaped the relatively newer Fisheries Licensing Policy for DFO's Newfoundland and Labrador Region, specifically for managing and regulating inshore commercial fisheries and plants on the coast and inland waters of NL (DFO 2018).

\section{Buddy-up and enterprise combining}

Although quotas in NL fisheries were not generally transferable in a fully commodified sense, other technologies of agency were developed enabling fish harvesters to combine quota and licenses temporarily and permanently. In 1996, the federal government introduced a policy called Buddy-up in the inshore sector, which was extended in 2006 to the nearshore sector (GOV NL 2011:29). The federal government describes buddying-up as a "temporary arrangement allowing a maximum of two license holders holding valid licenses for the same species, the same fishing area, and same gear type operating the same vessel" (DFO 2018). The rationales for developing the Buddy-up policy include economic goals of efficiency (e.g., reducing overhead costs), safety improvement goals (e.g., more harvesters working together to distribute the workload, with the option of fishing in a larger vessel), and crewing requirement improvements (e.g., when there is difficulty recruiting crew) (DFO 2019; also see Squires and Wiber 2018; Transportation Safety Board of Canada 2017). All of these rationales were reflected in comments made by research participants.

The Buddy-up policy has raised concerns and resulted in unintended outcomes, however. Some participants indicated that in some cases, the Buddy-up policy is being used to facilitate quota leasing and the collection of rent or royalties from the fishery by enterprise owners who no longer fish. As one interview participant explained, "in theory it [buddyup] is a really good idea. Basically, you have two people sharing the same vessel...but it's not policed and it gets abused, so people are not going on the water and they have somebody else who's catching their quota and they're getting a share...". This same concern has been expressed in the NL mid-shore fleet (Canada- NL) 2006:11). One interview participant suggested that prohibiting buddying-up in some groundfish fisheries prevents the approach from being used to circumvent the PIIFCAF policy that protects the inshore sector against encroaching corporate consolidation. Others within the industry are pressuring the government to extend the Buddy-up policy to all fisheries (DFO 2019), suggesting an ongoing tension in in the design of, and practices in, technologies of agency for inshore fish harvesters.

While the Buddy-up policy authorizes temporary licensecombining, other policy changes allow licenses to be permanently combined. In 2006, DFO introduced a policy called Enterprise Combining in the Canada/Newfoundland Fishing Industry Renewal Strategy (Canada- NL 2006). This policy emphasized fleet rationalization and was implemented with support from both federal and provincial governments. It enables a qualified fish harvester to buy another one out and 
combine the quotas from their two licenses under a single license resulting in the removal of one enterprise, vessel registration, and duplicate species licenses (Walsh 2011; Davis 2015:327; DFO 2018). In snow crab, up to three sets of inshore quotas can be combined under a single fishing enterprise (Davis 2015: 326). This combining of enterprises is restricted within specific fleets and geographic areas and is only allowed in "predominant fisheries," which, in addition to snow crab, include cod, Northern shrimp, and Gulf shrimp. Some licenses for other species can be combined with exceptions (DFO 2018). The process of combining enterprises is non-reversible, but a fish harvester may request to reallocate all, or a portion of, their quota acquired under the Enterprise Combining policy to another eligible fish harvester (DFO 2018).

As a technology of agency for fleet rationalization, enterprise combining is consistent with neo-liberal rationalization, but it also designed to support only those in the specified inshore sector and to support those remaining in the industry under conditions of labor contraction and quota reductions. Interview participants commented that it has been effective on both levels of rationalization; it has allowed DFO to reduce the number of active participants, and it has allowed fishermen to run more efficiently and increase the economic viability of their enterprises. For fish harvesters looking to retire, one participant noted that the sale of a license under enterprise combining provisions provides them with a solid financial base upon which to retire. However, other interview participants describe how enterprise combining has resulted in the de facto, if still constrained, commodification of fishing licenses, with exclusionary implications for subsequent generations looking to enter the fishery:

I know we tried to access [inshore] quota, and we are to blame as much as anyone else ... we're inflating the price of the license. A guy that is in with a company [through trust agreements] that wants to buy a quota, he is inflating the price. So where does that price go to make it sustainable for a guy to get into the fishery? Because it is at the point now where it is not sustainable.

The fishery is not sustainable, this harvester is arguing, in terms of the exclusionary effects of financialization. Even qualified inshore harvesters, who tend to come from modest socio-economic backgrounds, are experiencing increasing difficulty in securing large bank loans to buy vessels and licenses needed to participate in fisheries. The following quote suggests that the Enterprise Combining policy can increase incentives to circumvent owner-operator and fleet separation policies, whereby fish processing companies encourage fish harvesters to combine licenses through financing arrangements in exchange for guarantees to their catch. This increase in access to the resource can creep towards greater corporate control:

Just by way of background, processors are not allowed to control licenses that are used for inshore harvesting. They are separate from processors. [There is no] guaranteed supply for [the] plant. So, [processors] have to cut a deal with independent fishermen. And those fishermen have licenses and at times they are allowed to combine or acquire other licenses or parts of other licenses and that is how they gain access... to get access to more crab for example, one of the big ways that [processors] would do that is speak to a fisherman and encourage him to invest in another license. And [the processor] would finance that for him. [The processor] wouldn't own it, but would finance it, and loan him the money to buy out another fisherman.

This view was common, seeing the Enterprise Combining policy as offering a new means for commodification, financialization, and corporate concentration of access in the hands of a few that will eventually empty harbors of little boats and strip communities of their identity and attachment to the fishery. Although enterprise combining cannot be described as a full ITQ system due to limits on the number of quotas that can be merged and to the owner operator and fleet separation policies, it is nevertheless a transferable quota system that allows quotas to be bought and sold (Davis 2015: 327). It is, in other words, a technology of agency through which fish harvesters can play an active role in removing licenses from the system, and through which to trade quota as a commodity under certain constraints and conditions.

\section{Professionalization}

Another key technology of agency that encloses and opens access for inshore fish harvesters in NL is professionalization. Professionalization emerged broadly within Canadian fisheries but with particular characteristics in NL. By 1992, various fish harvester associations throughout Atlantic Canada had begun working with provincial authorities with jurisdiction over labor on professionalization criteria and standards. The professionalization of the inshore harvesting sector in NL emerged through discussions and consultations led by the FFAW-Unifor union and generally supported by fishing co-operatives, DFO, the provincial Department of Fisheries and Aquaculture at the time, and other government and educational institutions (PFHCB 2020a). The union developed a comprehensive certification system following consultations in more than 100 communities, involving more than 4,000 fish harvesters. At the time, there were four levels of accreditation: New Entrant, Level I, Level II, and Master Fisherman. New entrants would have to meet required 
standards of training and competency before participating in the fishery, while existing bona fida fishermen would be "grandfathered" into the system (DFO 1993). The report, chaired by former FFAW-Unifor president and co-founder Richard Cashin, explicitly articulated that professionalization would mean restricting access to the fishery and that fishermen who remained would "assume greater responsibility for the protection of the resource" and that self-regulation or co-management through professional organizations represents a shift in management responsibility and control (DFO 1993:72). It would become possible for fishermen to "be central players in any program to reduce excess capacity in the various fleets affected by the groundfish crisis" (DFO 1993:72). The objective would be "the creation of self-sustaining, viable fishery that benefits fishermen, coastal communities and the society at large" (DFO 1993: 67). By 1997, the Government of Newfoundland and Labrador House of Assembly passed the Professional Fish Harvesters Act, which facilitated the creation of the non-profit Professional Fish Harvesters Certification Board (PFHCB). The PFHCB then developed specific rules, requirements, and procedures for accreditation to enhance governability (for government authorities and the industry itself) and to empower fish harvesters to take greater responsibility for their own welfare and for the environment (Davis 2015: 325).

The formal purpose of professionalization is to distinguish full-time harvesters from those whose primary employment is outside of the fishery (PFHCB 2020b). Presently, there are three levels of accreditation and they include apprentice (new entrant), level 1, and level 2. As fish harvesters complete stages of training, they become qualified to further advance their career and qualifications to act and perform in particular ways as employees, laborers, crew, and owner-operators. To qualify, fish harvesters must earn $75 \%$ of their income from fishing during the fishing season. One research participant suggested that professionalization is important because "it lends some control over who can participate in the fishery" and prevents overcapacity by only certifying the number of harvesters required to meet the numbers under the limited entry licensing system:

...we are seeing an increase in the number of people pursuing [professionalization] upgrading... but at the same time we have to remember that in this province we still operate under a limited entry licensing system. So, there are only so many licenses that are going to become available...pretty basic principles of supply and demand.

The implementation of professionalization over time has created further tensions between enclosures and openings. Some protested that the criteria used in the program unfairly excluded and denied the benefits of fishing, while the union representing fish harvesters maintained their commitment to the idea that the benefits from future fisheries ought to be for those with more significant dependency on, and ties to, the fishery (Davis 2015). Dilemmas of enclosure and opening of access for inshore harvesters manifest in real challenges. For example, regulations stipulate that in order to acquire an existing complete "core" enterprise, an individual must be a level 2 professional, while a level 1 professional is eligible to be a substitute or "designated" operator (DFO 2018). On the one hand, this designated operator regulation was seen as an opportunity for new entrants to get some "time on the water" in order to advance to level 2 and develop relationships whereby an older fish harvester might "make a deal" and pass their enterprise on to a younger fish harvester. On the other hand, some research participants indicated that certain fish harvesters "want to designate forever," implying that some owner-operators use the designate provision as a means to unfairly circumvent the owner-operator policy. Others saw the certification process as overly stringent, thus hindering entry into the fishery by the younger generation and making it difficult to attain the credentials required to improve their status level. One participant described their current situation as such:

[I'm just designated as operator on the boat right now. To become eligible to be an owner-operator], I need more training, I need more sea time, and it's hard because I' $m$ only with a little tiny fishing enterprise, not big....Yeah, [reduction in quota] cuts into my sea time...luckily it counts being out in the shed and netting anything and everything else, if it wasn't for that, we're screwed.

Other research (Davis 2015; White 2015) reports similar responses from fish harvesters about difficulties in obtaining sea hours required for formal qualifications. The cost of training was even viewed by some fish harvesters as a deliberate attempt by government to phase out smaller enterprises and deter young people from pursuing fishing as a livelihood (Davis 2015).

At a general level, professionalization programs contain objectives of reducing the number of harvesters by eliminating fishers who have marginal reliance on the fishery (exclusionary rationalization) and protecting those who remained more strongly attached to or dependent upon it (inclusionary rationalization) (Clarke 2003). Overall, these challenges of professionalization and its relationship to other technologies of agency echo findings from studies that document harvesters who say they strongly believe, as Davis (2015: 326) puts it, that exclusion was justified "in order for the more established harvesters to make a better and more secure living, even though they...feared that this move toward enclosing the fishery could be a step toward the eventual privatization of what had historically been governed as a common resource." Such tensions and dilemmas 
illustrate the challenges of creating technologies of agency that simultaneously enclose and open access for inshore fish harvesters.

\section{Auditing, traceability, certification}

Certification and traceability programs, a technology of agency often fused with technologies of performance and markets, have become key sites of enacting and challenging neo-liberal governance. Seafood supply chains such as those in NL, which exports the vast majority of its seafood, have become subject to market-based sustainability certification and eco-labeling systems (Ponte 2012) within a broader global scramble for fisheries assessments (Foley et al. 2018). In August 2008, Northern shrimp, a key prey of the iconic Northern cod with populations adjacent to NL, became the first aquatic species managed by the Canadian government to meet the Marine Stewardship Council (MSC) environmental standard for "sustainable and well-managed" wild capture fisheries (Foley 2012: 438; Foley and McCay 2014). This was followed by the MSC certification of Snow Crab in 2013, and 3Ps Cod in 2016 which has subsequently been suspended (MSC 2020). At the same time, traceability of seafood has become increasingly important at the global scale, with both the USA and the European Union requiring traceability of seafood imports to ensure food safety, and to protect against the mislabeling of seafood, and distribution of illegal, unregulated, and unreported (IUU) fish (Oceana 2018a, b; NOAA 2020). With NL seafood products exported to more than 40 countries, including markets in the USA and in the European Union (Gov NL 2018), NL fish and seafood producers have had to adapt to comply with emerging regulations from export markets.

In this context, the union representing fish harvesters and fish processing plant workers became interested in developing an alternative technology of agency that might certify or trace information, credentials, and characteristics specific to NL's inshore fishery. While the MSC's environmental standard and traceability system represented a relatively narrow conservation rationality or environmentality (Foley et al. 2018), harvesters in NL began discussing alternative forms of recognition and reward such as producer-oriented traceability initiatives. Building on similar practices and collaborations developed elsewhere (Parlee and Wiber 2011), the NL-based Fisheries, Science Stewardship and Sustainability Board (FSSSB), in collaboration with a non-governmental organization, implemented a traceability program for Atlantic lobster and halibut (FFAW 2020; ThisFish 2020; SeafoodNL 2016). Fish harvesters viewed traceability as a technology of agency that might allow them to tell their story and to promote and communicate their own conceptions of production practices that should be recognized and rewarded, such as sustainability, product quality, ownership patterns of vessels, labor and safety conditions, and professionalization of the industry.

Yet alternative seafood marketing in a neo-liberal era means that the fish harvesters participate in the very processes they are resisting (Witter and Stoll 2017), highlighting further tensions in how changing governance affects the ability of fish harvesters to control access to, and benefits from, fisheries. The behavioral changes anticipated in these technologies do not always manifest (Parlee and Wiber 2011, 2014; Bresnihan 2019b) and they tend to increase the power of actors such as large-scale seafood buyers at the expense of less powerful suppliers and to cultivate and maintain competition among individual fish harvesters and among fleets, creating pressures for the development of "environmental entrepreneurs" (Parlee and Wiber 2014; also see Parlee and Wiber 2011; Foley et al. 2018; Bresnihan 2019b: 166). In the case of NL, the union representing fish harvesters and fish processing plant workers acted as this kind of entrepreneur, engaging with dominant neo-liberal technologies but also developing their own novel technologies by adapting those prevalent in neo-liberal institutions and processes.

\section{Conclusion}

This paper used the governmentality approach to analyze the micro-rationalities and technologies of governance in the making and re-making of fisheries governance in Newfoundland and Labrador. It demonstrates the contradictory and complex nature of diverse practices of regulatory enclosure and opening for inshore fish harvesters in NL. Regulatory change simultaneously creates and reduces opportunities for access to fisheries by small-scale harvesters, thereby challenging, refining, and revising current conceptions of neo-liberalism as having purely negative, regressive, and exclusionary outcomes. Regulatory change and its consequences are not only shaped by the powerful institutions of neo-liberalism but also by less dramatic policies, actions, and responses (Murray et al. 2010). Privatization policies of limited entry licensing and individual quotas were developed alongside owneroperator and fleet separation policies, which provide powerful institutional protections to prevent consolidated corporate ownership and vertical integration over fisheries. Over time, new practices of fish harvester credentialization (professionalization) and micro-consolidation (authorized through Buddy-up and Enterprise Combining policies) were driven by industry rationalization ideas (reducing numbers of workers and enhance economic efficiency) as well as by ideas to accommodate the needs and interests of fish harvesters committed to ensuring access to fisheries that support them making a living from the sea. The relationship of these policies and rationalities 
to neo-liberalism are contradictory and complex, then. If policies of professionalization, enterprise combining, and eco-labelling schemes are neo-liberal, they are substantially informed, moderated, managed, and regulated through a broader moral economy informed by specific social and coastal community protection principles, such as those defining the owner-operator and fleet separation policies. NL fisheries are, in other words, governed by multiple environmentalities, including those informed by moral economy rationalities, neo-liberal rationalities, and hybrid rationalities, all bound together in institutional contexts overwhelmingly accommodating to the most powerful and prevalent global and national rationalities and technologies of neo-liberalism but developing through both abrupt and less dramatic ways and relations.

The multiple and contradictory manifestations of neoliberal rationalities and technologies of governance in this case help explain the dynamic roll-out of what Murray et al. (2010) call "creeping" enclosure, which is the cumulative effects of multiple events and processes on fish harvesters. The cumulative effects can include both direct and indirect impacts, they can result from multiple forces pushing in different directions, and they do not necessarily feature attributes typically associated with neo-liberal approaches to fisheries management and governance. Like other enclosures, these are historically and geographically contingent (Peck and Tickell 2002: 383; McCarthy and Prudham 2004; Castree 2008; Bakker 2010). Ultimately, the history of contemporary fisheries governance in the Canadian province of Newfoundland and Labrador is characterized by power struggles and power relations, such as those shaping conflict and cooperation between harvesting and processing sectors over controlling access to the fishery and the ongoing activities of fish harvesters who are accommodating, challenging, and revising neoliberal technologies of government from state and nonstate actors. While the high-stake debates around different forms of quotas and access rights are understandably the focus of much research on neo-liberal fisheries governance, more research is needed to understand other technologies of government, such as hybrid quota models, license consolidation under conditions of restrictions against corporate ownership, professionalization, and producercontrolled traceability and eco-certification. These technologies are characterized by ongoing tensions between creeping enclosures and creeping openings. Such tensions are driven in part by power struggles and the agency of fish harvester organizations as they seek to keep open, and open up new, windows of opportunity to support their ideas and interests of social justice against the crudest aspects of the art of liberal governance.
Acknowledgements The authors would like to thank members of the Ocean Frontier Institute's Informing Governance Responses in a Changing Ocean research project for their support. They also thank the Environmental Policy Institute at Memorial University's Grenfell Campus for research support.

Funding Research funding was provided by the Ocean Frontier Institute, through an award from the Canada First Research Excellence Fund.

Availability of data and material Yes.

\section{Declarations}

Ethics approval Yes.

Consent to participate Yes.

Consent for publication Yes.

Competing interests The authors declare no competing interests.

Open Access This article is licensed under a Creative Commons Attribution 4.0 International License, which permits use, sharing, adaptation, distribution and reproduction in any medium or format, as long as you give appropriate credit to the original author(s) and the source, provide a link to the Creative Commons licence, and indicate if changes were made. The images or other third party material in this article are included in the article's Creative Commons licence, unless indicated otherwise in a credit line to the material. If material is not included in the article's Creative Commons licence and your intended use is not permitted by statutory regulation or exceeds the permitted use, you will need to obtain permission directly from the copyright holder. To view a copy of this licence, visit http://creativecommons.org/licenses/by/4.0/.

\section{References}

Alverson, D.L. 1987. A study of trends of cod stocks off Newfoundland and factors influencing abundance and availability to the inshore fishery. Ottawa: Department of Fisheries and Oceans.

Bakker, Karen. 2010. The limits of 'neoliberal natures': Debating green neoliberalism. Progress in Human Geography 34 (6): 715-735.

Barnett, Allain JD. 2014. From Policy Instruments to Action Arenas: Toward Robust Fisheries and Adaptive Fishing Households in Southwest Nova Scotia (Doctoral dissertation, ARIZONA STATE UNIVERSITY).

Barnett, Allain J., Robin A. Messenger, and Melanie G. Wiber. 2017. Enacting and contesting neoliberalism in fisheries: The tragedy of commodifying lobster access rights in Southwest Nova Scotia. Marine Policy 80: 60-68.

Bavinck, Maarten, Svein Jentoft, and Joeri Scholtens. 2018. Fisheries as social struggle: A reinvigorated social science research agenda. Marine Policy 94: 46-52.

Bresnihan, Patrick. 2016. Transforming the fisheries: neoliberalism, nature, and the commons. U of Nebraska Press.

Bresnihan, Patrick. 2019a. The (slow) tragedy of improvement: Neoliberalism, fisheries management \& the institutional commons. World Development 120: 210-220. 
Bresnihan, Patrick. 2019b. Revisiting neoliberalism in the oceans: Governmentality and the biopolitics of 'improvement' in the Irish and European fisheries. Environment and Planning a: Economy and Space 51 (1): 156-177.

Canada- Newfoundland and Labrador (Canada- NL). 2006. Fishing Industry Renewal Initiative: Discussion Paper. http://publications. gc.ca/collections/collection_2007/dfo-mpo/Fs114-5-2006E.pdf.

Carothers, Courtney. 2015. Fisheries privatization, social transitions, and well-being in Kodiak, Alaska. Marine Policy 61: 313-322.

Carothers, Courtney, and Catherine Chambers. 2012. Fisheries privatization and the remaking of fishery systems. Environment and Society 3 (1): 39-59.

Campling, Liam, and Elizabeth Havice. 2014. The problem of property in industrial fisheries. The Journal of Peasant Studies 41 (5): 707-727.

Castree, Noel. 2008. Neoliberalising nature: The logics of deregulation and reregulation. Environment and Planning A 40 (1): 131-152.

Clarke, Matthew. 2003. The professionalization of inshore fishers. In Retrenchment and regeneration in rural Newfoundland, ed. R. Byron, 134-157. Toronto: University of Toronto Press.

Davis, Reade. 2015. 'All in': Snow crab, capitalization, and the future of small-scale fisheries in Newfoundland. Marine Policy 61: 323-330.

Dean, Mitchell. 2010. Governmentality: Power and Rule in Modern Society. Thousand Oaks: Sage Publications Ltd.

Dean, Mitchell. 2017. Governmentality. The Wiley-Blackwell Encyclopedia of Social Theory, 1-2

Department of Fisheries and Oceans (DFO). 1993. Charting a New Course. Ottawa: Towards the Fishery of the Future.

DFO. 1993. Charting a New Course: Towards the Fishery of the Future. Report of the Task Force on Incomes and Adjustment in the Atlantic Fishery.

DFO. 1996. Commercial fisheries Licensing policy for Eastern Canada. https://www.dfo-mpo.gc.ca/reports-rapports/regs/licencespermis/index-eng.htm.

DFO. 2001. The Management of Fisheries on Canada's Atlantic Coast. Atlantic Fisheries Policy Review. http://publications.gc. ca/collections/Collection/Fs23-391-2000E.pdf, (Ottawa, CA).

DFO. 2017. Fisheries Licensing Policy Newfoundland and Labrador Region. http://www.dfo-mpo.gc.ca/reports-rapports/regs/licen ces-permis/nfld-Labrador-tn-labrador-eng.htm\#term, (DFO, Ottawa, Canada).

DFO. 2017. Information Note: Preserving the Independence of the Inshore Fleet in Canada's Atlantic Fisheries. https://www.dfompo.gc.ca/fisheries-peches/initiatives/piifcaf-pifpcca/note-bulle tin-eng.html

DFO. 2018. Fisheries Licensing Policy Newfoundland and Labrador Region. http://www.dfo-mpo.gc.ca/reports-rapports/regs/licen ces-permis/nfld-Labrador-tn-labrador-eng.htm (DFO, Ottawa, Canada).

DFO. 2019. Discussion on the Newfoundland and Labrador Inshore Fishery: A Summary of Comments from Public Discussions on the Future of Newfoundland and Labrador's Inshore Fishery. https:// waves-vagues.dfo-mpo.gc.ca/Library/40888940.pdf.

Edwards, Danielle N, and Evelyn Pinkerton. 2019. The hidden role of processors in an individual transferable quota fishery. Ecology and Society 24(3)

Edwards, Danielle N., and Evelyn Pinkerton. 2020. Priced out of ownership: quota leasing impacts on the financial performance of owner-operators. Marine Policy 111: 103718.

Elson v. Canada (Attorney General), 2017 FC 459 (CanLII). <https:// canlii.ca/t/h3p49>

Fisheries Act, R.S.C. 1985. c. F-14. https://www.canlii.org/en/ca/ laws/stat/rsc-1985-c-f-14/latest/rsc-1985-c-f-14.html

Foley, Paul. 2012. The political economy of Marine Stewardship Council certification: Processors and access in Newfoundland and Labrador's inshore shrimp industry. Journal of Agrarian Change 12 (2-3): 436-457.

Foley, Paul, and Bonnie McCay. 2014. Certifying the commons: ecocertification, privatization, and collective action. Ecology and Society $19(2)$

Foley, Paul. 2017. The territorialization of transnational sustainability governance: Production, power and globalization in Iceland's fisheries. Environmental Politics 26 (5): 915-937.

Foley, Paul. 2019a. A Coxian perspective on transnational business governance interactions: counter-hegemonic certification movements in fisheries. In Transnational business governance interactions. Edward Elgar Publishing.

Foley, Paul. 2019b. Social-ecological reproduction and the substance of life in commodity frontiers: Newfoundland fisheries in world market shifts. Capital \& Class 43 (4): 543-560.

Foley, Paul, and Elizabeth Havice. 2016. The rise of territorial ecocertifications: New politics of transnational sustainability governance in the fishery sector. Geoforum 69: 24-33.

Foley, Paul, and Karen Hebért. 2013. Alternative regimes of transnational environmental certification: Governance, marketization, and place in Alaska's salmon fisheries. Environment and Planning A 45 (11): 2734-2751.

Foley, Paul, and Charles Mather. 2019. Ocean grabbing, terraqueous territoriality and social development. Territory, Politics, Governance 7 (3): 297-315.

Foley, Paul, Charles Mather, and Barbara Neis. 2015. Governing enclosure for coastal communities: Social embeddedness in a Canadian shrimp fishery. Marine Policy 61: 390-400.

Foley, Paul, Dinah A. Okyere, and Charles Mather. 2018. Alternative environmentalities: recasting the assessment of Canada's first Marine Stewardship Council-certified fishery in social terms. Ecology and Society 23(3). https://doi.org/10.5751/ ES-10382-230337

FFAW. 2020. Seafood traceability. https://ffaw.ca/sectors/fisheries/ seafood-traceability/

Foucault, Michel. 1991. Governmentality. In The Foucault Effect. Studies in Governmentality, ed. Graham Burchell, Colin Gordon, and Peter Miller, 87-104. Chicago: The University of Chicago Press.

Fletcher, Robert. 2010. Neoliberal environmentality: Towards a poststructuralist political ecology of the conservation debate. Conservation and Society 8 (3): 171-181.

Fletcher, Robert. 2017. Environmentality unbound: Multiple governmentalities in environmental politics. Geoforum 85: 311-315.

Gibson-Graham, Julie Katherine. 2006. A postcapitalist politics. Minneapolis, MN: University of Minnesota Press.

Gibson-Graham, Julie Katherine. 2008. Diverse economies: Performative practices for other worlds'. Progress in Human Geography 32 (5): 613-632.

Government of Newfoundland and Labrador (GOV NL). 2011. Report of the Independent Chair: MOU Steering Committee. Newfoundland and Labrador fishing industry rationalization and restructuring, https://www.gov.nl.ca/ffa/files/publications-pdf-mou.pdf

Government of Newfoundland and Labrador (GOV NL). 2018. Seafood Industry Year in Review 2018. https://www.gov.nl.ca/ffa/ files/publications-pdf-syir-2018.pdf.

Hache, J.E. 1989. Report of the Scotia-Fundy Task-Force, 86. Ottawa: Department of Fisheries and Oceans.

Harris, Leslie. 1990. Independent review of the state of the northern cod stock. Ottawa: Department of Fisheries and Oceans.

Johnsen, JahnPetter. 2017. Creating political spaces at sea-governmentalisation and governability in Norwegian fisheries. Maritime Studies 16 (1): 1-24.

Kirby, Michael JL. 1982. Navigating troubled waters. The Task Force

Larner, Wendy. 2000. Neo-liberalism: Policy, ideology, governmentality. Studies in Political Economy 63 (1): 5-25. 
Lear, W. Henry., and L.S. Parsons. 1993. History and management of the fishery for northern cod in NAFO Divisions $2 \mathrm{~J}, 3 \mathrm{~K}$ and $3 \mathrm{~L}$. Perspectives on Canadian marine fisheries management. Edited by LS Parsons and WH Lear. Canadian Bulletin of Fisheries and Aquatic Sciences 226: 55-90.

Konefal, Jason. 2013. Environmental movements, market-based approaches, and neoliberalization: A case study of the sustainable seafood movement. Organization \& Environment 26 (3): 336-352.

Marine Stewardship Council. 2020. Track a Fishery, fisheries.msc.org.

Mansfield, Becky. 2004. Rules of privatization: Contradictions in neoliberal regulation of North Pacific fisheries. Annals of the Association of American Geographers 94 (3): 565-584.

Matthews, Ralph. 1988. Federal licencing policies for the Atlantic inshore fishery and their implementation in newfoundland, 19731981. Acadiensis 17 (2): 83-108.

McCarthy, James, and Scott Prudham. 2004. Neoliberal nature and the nature of neoliberalism. Geoforum 35 (3): 275-283.

McCay, Bonnie J. 1999. That's not right': resistance to enclosure in a Newfoundland crab fishery. Fishing Places, Fishing People. Traditions and Issues in Canadian Small-Scale Fisheries, ed. D Newell and R Ommer, 301-318.

McKee, Kim. 2009. Post-Foucauldian governmentality: What does it offer critical social policy analysis? Critical Social Policy 29 (3): 465-486.

Miller, Peter, and Nikolas Rose. 2008. Governing the present: Administering economic, social and personal life. Cambridge UK: Polity Press.

National Oceanic and Atmospheric Administration. 2020. U.S. Seafood Import Monitoring Program. https://www.iuufishing.noaa.gov/ RecommendationsandActions/RECOMMENDATION1415/Final RuleTraceability.aspx

Murray, Grant, Teresa Johnson, Bonnie McCay, Mike Danko, Kevin St Martin, and Satsuki Takahashi. 2010. Cumulative effects, creeping enclosure, and the marine commons of New Jersey. International Journal of the Commons 4(1)

Neis, Barbara, Rosemary Ommer, Doug House, Winston Fiander, Paul Foley, Ian A. Fleming, Carolyn Lavers, Bonnie McCay, Peter R. Sinclair, and Keith Sullivan. 2014. Building economically, socially and ecologically resilient fisheries and coastal communities: a policy paper. https://research.library.mun.ca/8432/1/Revis ed_CURRA_Policy_Paper_April_16_2014.pdf

Oceana. 2018a. CFIA's New Food Regulations Miss the Boat on Seafood Traceability: Oceana Canada calls on Canada to align with international best practices. https://oceana.ca/fr/presse/commu niques-de-presse/cfias-new-food-regulations-miss-boat-seafoodtraceability-oceana-canada

Oceana. 2018b. Seafood Fraud and Mislabelling Across Canada. https://oceana.ca/en/publications/reports/seafood-fraud-and-misla belling-across-canada.

Olson, Julia. 2011. Understanding and contextualizing social impacts from the privatization of fisheries: An overview. Ocean \& Coastal Management 54 (5): 353-363.

Parlee, Courtenay E., and Melanie G. Wiber. 2011. Who is governing food systems? Power and legal pluralism in lobster traceability. The Journal of Legal Pluralism and Unofficial Law 43 (64): 121-148.

Parlee, Courtenay E., and Melanie G. Wiber. 2014. Institutional innovation in fisheries governance: Adaptive co-management in situations of legal pluralism. Current Opinion in Environmental Sustainability 11: 48-54.

Peck, Jamie, and Tickell Adam. 2002. Neoliberalizing Space. Antipode 34 (3): 380-202.

Pinkerton, Evelyn. 2013. Alternatives to ITQs in equity-efficiencyeffectiveness trade-offs: How the lay-up system spread effort in the BC halibut fishery. Marine Policy 42: 5-13.
Pinkerton, Evelyn. 2017. Hegemony and resistance: Disturbing patterns and hopeful signs in the impact of neoliberal policies on smallscale fisheries around the world. Marine Policy 80: 1-9.

Pinkerton, Evelyn, and Reade Davis. 2015. Neoliberalism and the politics of enclosure in North American small-scale fisheries. Marine Policy 61: 303-312.

Professional Fish Harvesters Certification Board (PFHCB). 2020a. Maintenance and Status. https://www.pfhcb.com/maint enance-of-status.

Professional Fish Harvesters Certification Board (PFHCB). 2020b. (https://www.pfhcb.com/background-of-the-pfhcba) $/$

Ponte, Stefano. 2012. The Marine Stewardship Council (MSC) and the making of a market for 'sustainable fish.' Journal of Agrarian Change 12 (2-3): 300-315.

Rose, Nikolas. 1999. Powers of freedom: Reframing political thought. Cambridge university press

Said, Alicia, Joseph Tzanopoulos, and Douglas MacMillan. 2016. Bluefin tuna fishery policy in Malta: The plight of artisanal fishermen caught in the capitalist net. Marine Policy 73: 27-34.

Smith, Derek., Woodrow, Maureen., and Vodden, Kelly. (2012) Policy Brief No. 1: Fisheries Rationalization. https://gracilis.carleton.ca/ tgeog/downloads/Using/Local/Knowledge,/PB/1/(June/2012).pdf

SeafoodNL. 2016. Trace your fish. http://www.seafoodnl.ca/index.php/ traceability

Squires, Kevin, and Melanie G. Wiber. 2018. Distribution of fishery benefits and community well-being. Ecology and Society 23(2)

St. Martin, Kevin. 2005a. Mapping economic diversity in the First World: The case of fisheries. Environment and Planning A 37 (6): 959-979.

St. Martin, Kevin. 2005b. Disrupting enclosure in New England fisheries. Capitalism Nature Socialism 16 (1): 63-80.

St. Martin, Kevin. 2007. The difference that class makes: Neoliberalization and non-capitalism in the fishing industry of New England. Antipode 39 (3): 527-549.

Stephenson, Robert L., Stacey Paul, Melanie G. Wiber, Eric Angel, Ashleen J. Benson, Anthony Charles, Omer Chouinard, M. Clemens, D. Edwards, P. Foley, L. Jennings, O. Jones, D. Lane, J. McIsaac, C. Mussells, B. Neis, B. Nordstrom, C. Parlee, E. Pinkerton, M. Saunders, K. Squires, and U.R. Sumaila. 2018. Evaluating and implementing social-ecological systems: A comprehensive approach to sustainable fisheries. Fish and Fisheries 19 (5): 853-873. https://doi.org/10.1111/faf.12296.

Stephenson, Robert L., Melanie G. Wiber, Stacey Paul, Eric Angel, Ashleen Benson, Anthony Charles, Omer Chouinard, D. Edwards, P. Foley, D. Lane, J. McIsaac, B. Neis, C. Parlee, E. Pinkerton, M. Saunders, K. Squires, and U.R. Sumaila. 2019. Integrating diverse objectives for sustainable fisheries in Canada. Canadian Journal of Fisheries and Aquatic Sciences 76 (3): 480-496. https://doi. org/10.1139/cjfas-2017-0345.

ThisFish 2020 https://this.fish/fishery/species/atlantic-lobster/. Accessed on January 6, 2020.

Transportation Safety Board of Canada. 2017. Marine Investigation report M16A0327. Sinking and Subsequent Loss of Life: Small open fishing vessel Pop's Pride Cape Spear, Newfoundland and Labrador, September 6, 2016. https://www.bst-tsb.gc.ca/eng/rappo rts-reports/marine/2016/m16a0327/m16a0327.pdf.

Walsh, Deata. 2011. What restructuring? Whose rationalization? Newfoundland and Labrador's memorandum of understanding on its fishing industry. World small-scale fisheries contemporary visions, ed. R Chuenpagdee, 81-97

White, Carole Sandrine. 2015. Getting into Fishing: Recruitment and Social Resilience in North Norfolk's 'Cromer Crab' fishery, UK. Sociologia Ruralis 5 (3): 292-308. https://doi.org/10.1111/soru. 12101.

Young, Oran R., D.G. Webster, Michael E. Cox, Jesper Raakjær, Lau Øfjord Blaxekjær, Níels. Einarsson, Ross A. Virginia, J. Acheson, 
D. Bromley, E. Cardwell, and C. Carothers. 2018. Moving beyond panaceas in fisheries governance. Proceedings of the National Academy of Sciences 115 (37): 9065-9073.

Witter, Allison, and Joshua Stoll. 2017. Participation and resistance: Alternative seafood marketing in a neoliberalera. Marine Policy 80: 130-140.
Publisher's note Springer Nature remains neutral with regard to jurisdictional claims in published maps and institutional affiliations. 